\title{
PERBEDAAN KANDUNGAN SERAT PANGAN PADA MAKANAN SIAP SAJI KHAS INDONESIA YANG DIANALISIS DENGAN MENGGUNAKAN NUTRISURVEY DAN ENZIMATIK GRAVIMETRI
}

\author{
Inggita Kusumastuty ${ }^{\star 凶}$, Leny Budhi Harti* , Sofie Ayu Misrina*
}

\begin{abstract}
Abstrak
Serat pangan memiliki manfaat bagi kesehatan salah satunya mengontrol berat badan atau kegemukan. Terdapat dua metode dalam menentukan kandungan serat makanan yaitu uji laboratorium metode enzimatik gravimetri dan software contohnya nutrisurvey. Nutrisurvey tidak membutuhkan biaya yang mahal, praktis, dan cepat dibandingkan dengan uji laboratorium. Sementara, uji laboratorium merupakan metode yang dijadikan gold standart dalam menentukan kandungan gizi makanan. Penelitian ini bertujuan untuk menganalisis kandungan serat pangan pada 15 makanan siap saji khas Indonesia dengan menggunakan nutrisurvey dan enzimatik gravimetri serta melihat ada tidaknya perbedaan dari kedua metode tersebut. Rancangan penelitian yang digunakan adalah observasional analisis, yaitu sampel yang telah ditentukan kemudian dikumpulkan untuk diobservasi kandungan serat pangan. Data dianalisis menggunakan uji Mann Whitney. Hasil penelitian menunjukkan serat pangan yang dianalisis dengan nutrisurvey memiliki rata-rata standar deviasi 5,10 \pm 4,28 gram. Serat pangan yang diuji dengan metode enzimatis gravimetri memiliki ratarata standar deviasi $\overline{3} 6,53 \pm 14,05$ gram. Terdapat perbedaan yang signifikan antara serat pangan yang diuji dengan nutrisurvey dan enzimatik gravimetri $(p=0,00)$. Kesimpulan dari penelitian ini adalah terdapat perbedaan kandungan serat pangan pada analisis nutrisurvey dan enzimatik gravimetri.
\end{abstract}

Kata Kunci : enzimatik gravimetri , nutrisurvey, serat pangan.

\section{DIFFERENCES OF DIETARY FIBER CONTENT IN 15 INDONESIAN FAST FOOD ANALYZED WITH NUTRISURVEY AND ENZYMATIC GRAVIMETRIC}

\begin{abstract}
Dietary Fiber has health benefits one of them to control obesity and weight. There are two methods to determine fiber in our food that are nutrisurvey and enzymatic gravimetric. Nutrisurvey is cheaper, easy to perform, and faster compare to laboratory test. However, laboratory test is a gold standard method for dietary fiber analysis. This research was to analyse dietary fiber content in 15 Indonesian fast food by using nutrisurvey and enzymatic gravimetric methods and to compare between those methods. The research used observational analysis, the selected samples were then analyzed their dietary fiber. The data were analyzed statistically by using Mann Whitney test. The result from nutrisurvey analysis showed that dietary fiber content was about $5.10+4.28 \mathrm{~g}$. Enzymatic gravimetric analysis showed that dietary fiber content was about $36.53+14.05 \mathrm{~g}$. There was significant different on dietary fiber content analyzed with nutrisurvey and enzymatic gravimetric test $(p=0,00)$. To conclude, there was difference on dietary fiber content in 15 Indonesian fast food that tested with nutrisurvey and enzymatic gravimetric.
\end{abstract}

Keywords: dietary fiber, enzymatic gravimetric, nutrisurvey.

* Program Studi IImu Gizi, FKUB

E-mail: inggita.kusuma@gmail.com 


\section{Pendahuluan}

Obesitas pada saat ini telah menjadi masalah kesehatan dan berhubungan dengan terjadinya peningkatan penyakit tidak menular. Dalam 10 tahun terakhir ini, angka prevalensi atau kejadian obesitas di seluruh dunia menunjukkan peningkatan yang signifikan. Pada tahun 2014 lebih dari 1,9 milyar orang overweight dan lebih dari 600 juta orang obesitas. Sebanyak 39\% pada usia lebih 18 tahun mengalami overweight dan $13 \%$ mengalami obesitas. ${ }^{1}$ Data Riskesdas tahun 2013 menunjukkan prevalensi gizi lebih di Indonesia pada kelompok anak usia 5-12 tahun sebesar $18,8 \%, 13-15$ tahun sebesar 10,8\%, 16-18 tahun sebesar $7,3 \%$ dan dewasa sebesar $28,9 \%$.

Kegemukan (obesitas) adalah kelebihan lemak tubuh. Obesitas terjadi karena ketidakseimbangan energi antara kalori yang dikonsumsi dan kalori yang dikeluarkan. Adanya peningkatan konsumsi makanan padat energi yang tinggi lemak serta dikombinasikan dengan penurunan aktifitas fisik dalam jangka waktu lama akan menyebabkan seseorang mengalami obesitas ${ }^{1,2}$.

Akhir-akhir ini terdapat perubahan pola konsumsi makanan di Indonesia, yaitu masyarakat Indonesia lebih banyak mengkonsumsi makanan modern dibandingkan dengan konsumsi makanan siap saji khas Indonesia. Makanan modern dicirikan dengan tinggi energi, rendah serat, tinggi lemak. Pola konsumsi inilah yang dapat menyebabkan kegemukan (obesitas) dan menjadi faktor resiko penyakit seperti jantung koroner, kanker kolon (usus besar), dan penyakit degeneratif lainnya di Indonesia.

Serat pangan merupakan bagian dari tumbuhan yang dapat dikonsumsi yang memiliki sifat resistan terhadap proses pencernaan dan penyerapan di usus halus manusia serta mengalami fermentasi sebagian atau keseluruhan di usus besar. Serat pangan memiliki manfaat bagi kesehatan salah satunya yaitu berfungsi mengontrol berat badan atau kegemukan. ${ }^{3}$

Salah satu cara yang dapat dilakukan dalam menangani kegemukan (obesitas) adalah dengan memberikan pendidikan gizi terkait label pangan dan informasi nilai gizi pada makanan terutama serat pangan. Di Indonesia pencantuman label pangan pada kemasan sangat terbatas, karena tidak semua makanan harus mencantumkan adanya label pangan. Pangan yang tidak mencantumkan label pangan yaitu pangan yang dibungkus dihadapan pembeli. ${ }^{4}$ Adanya pengecualian tersebut, masih banyak makanan siap saji khas Indonesia yang tidak mencantumkan label pangan serta kandungan gizinya sehingga diperlukan analisis kandungan zat gizi pada makanan siap saji khas Indonesia untuk diinformasikan kepada masyarakat.

Terdapat 2 metode dalam menentukan kandungan zat gizi suatu makanan yaitu software dan uji laboratorium. Software yang digunakan dalam menganalisis kandungan zat gizi adalah Nutrisurvey. Nutrisurvey merupakan suatu program yang memungkinkan seorang profesional gizi untuk menganalisis kandungan zat gizi bahan makanan dan atau resep makanan, menentukan kebutuhan zat gizi, menentukan status gizi, serta menyajikan datadata tersebut dengan beragam. ${ }^{5}$ Sementara itu, uji laboratorium yang digunakan adalah enzimatik gravimetri. Metode enzimatik gravimetri dilakukan dengan cara menghidrolisis pati dan protein dengan enzim. Metode ini dapat mengukur kadar serat makanan total, serat larut dan tak larut secara terpisah.

Nutrisurvey tidak membutuhkan biaya yang mahal, praktis, dan cepat dibandingkan dengan enzimatik gravimetri. Namun dibalik kemudahan analisis zat gizi menggunakan nutrisurvey terdapat berbagai kelemahan yang ditemukan diantaranya analisis kandungan zat gizi kurang tepat karena tidak semua bahan makanan memiliki bentuk pengolahannya pada nutrisurvey. 
Selain itu dibutuhkan ketelitian untuk menganalisis penyerapan minyak dan mengestimasi berat bahan penyusun. Adanya kelemahan tersebut, uji laboratorium metode enzimatik gravimeteri dijadikan sebagai gold standart dalam menentukan kandungan zat gizi dalam makanan. Berdasarkan uraian di atas penelitian ini bertujuan untuk menganalisis kandungan serat makanan siap saji khas Indonesia dengan menggunakan nutrisurvey dan enzimatik gravimetri serta melihat apakah terdapat perbedaan dari kedua metode tersebut.

\section{Bahan dan Metode}

\section{Desain Penelitian}

Penelitian ini merupakan penelitian observasional analisis yaitu sampel yang telah ditentukan kemudian dikumpulkan untuk diobservasi kandungan serat pangan dalam makanan tersebut.

\section{Populasi dan Sampel}

Populasi pada penelitian ini adalah makanan siap saji khas Indonesia yang berada di kota Malang. Penelitian ini menggunakan sampel makanan sejumlah 15 sampel berdasarkan penelitian Hanifa (2014) menurut tingkat kepopuleran menu dan kandungan kalori dengan rentang 500-600 kkal yang memenuhi $\pm 30 \%$ dari kebutuhan orang pada umumnya dengan jumlah 15 sampel.

\section{Tempat dan Waktu penelitian}

Penelitian ini dilaksanakan di wilayah kota Malang, serta di Laboratorium Diet Universitas Brawijaya dan Laboratorium Kimia Universitas Muhammadiyah Malang.

\section{Variabel Penelitian}

Variabel bebas pada penelitian ini adalah makanan siap saji khas Indonesia di kota Malang. Variabel terikat adalah kadar serat pangan.

\section{Definisi Operasional}

Definisi operasional dalam penelitian ini adalah

1. Makanan siap saji khas Indonesia: makanan lokal yang berasal dari Indonesia khususnya berada di kota malang yang biasa dikonsumsi oleh masyarakat, sejumlah 15 jenis makanan.

2. Serat pangan: total keseluruhan serat yang terdapat dalam makanan siap saji khas Indonesia baik itu serat larut maupun serat tidak larut dengan satuan gram.

\section{Pengambilan data}

Pengumpulan data dilakukan dengan metode purposive sampling yaitu penulis menentukan jenis makanan yang akan diteliti. Kemudian makanan yang sudah ditentukan, dikumpulan dari berbagai warung/rumah makan yang tersebar di kota Malang berdasarkan penelitian terdahulu, serta makanan yang memiliki rentang energi yang sama sebanyak 15 jenis makanan siap saji khas Indonesia.

\section{Analisis Serat Pangan}

Sampel yang telah ditentukan kemudian dipisahkan setiap bahannya untuk ditimbang kemudian dianalisis setiap bahan tersebut untuk melihat nilai serat pangan dengan menggunakan nurtisurvey. Untuk uji laboratorium makanan diblender terlebih dahulu agar homogen kemudian diambil sampelnya untuk dianalisis kandungan serat pangannya dengan menggunakan metode enzimatik gravimetri.

\section{Analisis Data}

Hasil dari nurtisurvey dan uji enzimatik gravimetri dianalisis dengan menggunakan software SPSS 16. Namun terlebih dahulu dilakukan uji normalitas dengan Shapiro-Wilk karena sampel kurang dari 50 . Uji perbedaan dilakukan dengan uji Mann Whitney karena data tidak terdistribusi dengan normal. Hasil 
penelitian dikatakan memiliki perbedaan yang bermakna apabila $p \leq 0,05 .^{6}$

Hasil

Berdasarkan hasil penelitian (Tabel 1) menunjukkan bahwa kandungan serat yang bersumber dari sayuran seperti selada, mentimun, tomat, kol, daun singkong. Sayuran merupakan bahan makanan yang mengandung jumlah serat baik serta larut dan tidak larut yang nilainya paling tinggi diantara bahan makanan yang lain. Selain itu makanan siap saji khas Indonesia ini memiliki rata rata berat makanan tiap porsi \pm 500 gram serta metode pengolahan yang digunakan bervariasi seperti dikukus, direbus, ditumis, digoreng dan disajikan segar.

Tabel 1. Rincian menu makanan siap saji khas indonesia

\begin{tabular}{|c|c|c|c|}
\hline Menu Makanan & Berat (gram) & Metode Pengolahan & Komposisi Sayuran \\
\hline Iga Bakar Mas Giri & 567 & $\begin{array}{l}\text { Dibakar, digoreng, dikukus, } \\
\text { disajikan segar }\end{array}$ & $\begin{array}{l}\text { Tomat, ketimun, } \\
\text { selada }\end{array}$ \\
\hline Soto Ayam Lamongan & 782 & Direbus, dikukus & Kol \\
\hline Sop Ayam Pak Min & 905 & Direbus, dikukus & - \\
\hline Bubur Ayam Abah Odil & 302 & Digoreng, direbus & - \\
\hline Rawon Bu Gito & 675 & Direbus dan dikukus & Toge kacang hijau \\
\hline Nasi Padang Roda Biru & 852 & Direbus, dikukus, ditumis & $\begin{array}{l}\text { Daun singkong, } \\
\text { tomat }\end{array}$ \\
\hline Bakso Presiden & 447 & Digoreng, direbus, dikukus & - \\
\hline Pangsit Mie Dempo & 602 & Direbus, digoreng & Selada, ketimun \\
\hline Mie Godok Jogja Pak Karso & 558 & Direbus, digoreng & Kol, ketimun \\
\hline Mie Goreng Joja Pak Karso & 483 & Direbus, ditumis, digoreng & Kol, ketimun \\
\hline Ayam Pak Maning & 837 & Digoreng, dikukus & $\begin{array}{l}\text { Daun kemangi, } \\
\text { ketimun, toge kacang } \\
\text { hijau, kacang } \\
\text { panjang, daun } \\
\text { singkong }\end{array}$ \\
\hline Ayam Goreng Jogja & 644 & Digoreng, dikukus & $\begin{array}{l}\text { Tomat, daun } \\
\text { kemangi, kacang } \\
\text { panjang, ketimun, } \\
\text { kol, selada }\end{array}$ \\
\hline Sate Gule Paino & 395 & Dibakar, digoreng, dikukus & - \\
\hline Bebek Goreng Slamet & 367 & Digoreng, ditumis, dikukus & $\begin{array}{l}\text { Daun kemangi, } \\
\text { ketimun, kol }\end{array}$ \\
\hline Sate Pak Siboen & 354 & Dibakar, digoreng, dikukus & - \\
\hline
\end{tabular}

Pada Tabel 2 diketahui bahwa kandungan serat makanan siap saji khas Indonesia yang dianalisis dengan enzimatik gravimetri, menunjukkan nilai yang jauh lebih tinggi dibandingkan dengan kandungan serat yang diuji dengan nutrisurvey. Nilai median untuk kandungan serat pada nutrisurvey sebesar 3,6 dengan rata-rata standar deviasi $5,10 \pm 4,28 \mathrm{~g}$ dan nilai median untuk kandungan serat pada enzimatik gravimetri sebesar 35 dengan rata-rata standar deviasi $36,53 \pm 14,05$ 
Tabel 2. Analisis statistik kandungan serat pada makanan siap saji khas Indonesia

\begin{tabular}{lcc}
\hline Menu Makanan & $\begin{array}{c}\text { Nilai Serat Uji } \\
\text { Nutrisurvey (gram) }\end{array}$ & $\begin{array}{c}\text { Nilai Serat Uji Lab } \\
\text { (gram) }\end{array}$ \\
\hline Iga Bakar Mas Giri & 1,8 & 35 \\
Soto Ayam Lamongan & 2,3 & 36 \\
Sop Ayam Pak Min & 3,5 & 45 \\
Bubur Ayam Abah Odil & 1,3 & 16 \\
Rawon Bu Gito & 1,6 & 37 \\
Nasi Padang Roda Biru & 17,3 & 51 \\
Bakso Presiden & 1,7 & 27 \\
Pangsit Mie Dempo & 6,2 & 32 \\
Mie Godok Jogja Pak Karso & 5 & 28 \\
Mie Goreng Joja Pak Karso & 6,3 & 36 \\
Ayam Pak Maning & 10,4 & 76 \\
Ayam Goreng Jogja & 7,7 & 45 \\
Sate Gule Paino & 2,3 & 32 \\
Bebek Goreng Slamet & 5,5 & 27 \\
Sate Pak Siboen & 3,6 & 25 \\
\hline Rata-rata + SD & $5,10+4,28$ & $36,53 \pm 14,05$ \\
\hline Median & 3,6 & 0,000 \\
\hline Nilai p (uji beda) & & \\
\hline
\end{tabular}

\section{Pembahasan}

\section{Kandungan Serat Pangan Makanan Siap} Saji Khas Indonesia Berdasarkan Metode Nutrisurvey

Berdasarkan Angka Kecukupan Gizi tahun 2013, anjuran konsumsi serat di Indonesia untuk orang dewasa sebesar 30$38 \mathrm{~g} / \mathrm{hari}$, dengan anjuran konsumsi setiap satu kali makan sebesar $10 \mathrm{~g} /$ porsi. Berdasarkan metode analisis nutrisurvey, didapatkan bahwa makanan siap saji khas Indonesia rata-rata memiliki kandungan serat sebesar 4,28-5,10 g/porsi. Penelitian ini menunjukkan bahwa menu makanan tradisional khas indonesia yang dianalisis dengan nutrisurvey belum memenuhi anjuran konsumsi serat setiap satu kali makan. Konsumsi makanan yang rendah serat (dibawah anjuran AKG) dapat menyebabkan seseorang cepat merasa lapar, sehingga konsumsi makanan tinggi energi meningkat. Konsumsi makanan tinggi energi dan kurangnya aktifitas fisik menyebabkan obesitas. Sehingga konsumsi rendah serat merupakan salah satu faktor terjadinya obesitas. ${ }^{7,8}$
Menu makanan Nasi Padang Roda Biru merupakan menu makanan yang memiliki kandungan serat pangan paling tinggi dengan nilai serat pangan sebesar 17,3 g/porsi. Hal ini karena menu nasi padang roda biru memiliki kandungan serat yang berasal dari santan, cabai, daun singkong dan nasi dalam porsi besar. Sementara itu, menu Bubur Ayam Abah Odil merupakan menu makanan yang memiliki kandungan serat paling rendah dengan nilai serat pangan sebesar 1,3 g/porsi, karena menu ini tidak terdiri dari bahan makanan sumber serat (seperti sayuran, kacang-kacangan) sama sekali.

\section{Kandungan Serat Pangan Makanan Siap Saji Khas Indonesia Berdasarkan Metode Enzimatik Gravimetri}

Pada analisis enzimatik gravimetri didapatkan bahwa makanan siap saji khas Indonesia rata-rata memiliki kandungan serat sebesar 14,05-36,53 g/porsi. Sehingga dapat dikatakan bahwa menu makanan tradisional khas indonesia yang dianalisis dengan enzimatik gravimetri melebihi anjuran konsumsi serat setiap satu kali makan. Konsumsi serat yang berlebihan tidak akan 
memberikan manfaat lebih, justru memiliki efek merugikan bagi kesehatan yaitu kram, diare, flatulens serta mengganggu penyerapan vitamin dan mineral. 9,10

Menu makanan Ayam Goreng Pak Maning merupakan menu makanan yang memiliki kandungan serat pangan paling tinggi dengan nilai serat pangan sebesar 76,21 g/porsi. Sementara menu Bubur Ayam Abah Odil merupakan menu makanan yang memiliki kandungan serat paling rendah dibandingkan dengan nilai serat pangan sebesar 16,05 g/porsi. Adanya perbedaan nilai serat yang jauh pada kedua menu ini disebabkan oleh menu Ayam Goreng Pak Maning memiliki bahan makanan sumber serat seperti kelapa, sambal dan berbagai sayuran (ketimun, kacang panjang, tauge, daun kemangi, daun singkong), sedangkan kandungan serat pada menu Bubur Ayam Abah Odil hanya berasal dari bubur nasi dan tepung.

Perbedaan Kandungan Serat Makanan Siap Saji Khas Indonesia dengan Analisis Nutrisurvey dan Enzimatik Gravimetri

Kandungan serat pangan yang diuji dengan metode uji laboratorium pada makanan siap saji khas Indonesia rata-rata memiliki kandungan yang tinggi dibandingkan dengan yang diuji dengan nutrisurvey. Hal ini sejalan dengan penelitian yang membandingkan antara analisis laboratorium dan software Unilever Dietary Analysis Program (UNIDAP) pada resep tradisional
Yunani. Hasil dari penelitian tersebut menunjukkan bahwa, terdapat perbedaan yang signifikan pada salah satu menu antara kadar serat makanan dengan analisis laboratorium dan software. ${ }^{11}$

Selain itu, hasil dari penelitian yang memvalidasi daftar komposisi makanan dengan analisis laboratorium, juga membuktikan bahwa daftar komposisi makanan tidak dapat digunakan untuk menganalisis kandungan serat makanan. ${ }^{12}$ Adanya perbedaan kandungan serat dari dua metode tersebut kemungkinan bergantung pada berbagai faktor, yaitu metode yang dipilih dalam analisis uji laboratorium, serta pengaruh pengolahan makanan yang tidak terdapat dalam analisis nutrisurvey.

Metode enzimatik untuk menentukan kandungan serat pangan total yang dikembangkan oleh AOAC (Official, 2000) pada saat ini digunakan sebagai metode referensi di banyak negara di seluruh dunia, terutama Amerika Serikat. AOAC ini merupakan metode yang ditetapkan sebagai gold standart dalam menentukan kandungan serat. Langkah dalam menentukan kandungan serat pangan dalam makanan dengan metode yang dikembangkan oleh Asp et al ini tidak jauh berbeda dengan AOAC. 13,14 Perbedaan yang terdapat dalam dua metode ini berupa penggunaan enzim pada hidrolisis pati dan protein, yang dapat dilihat pada Tabel 3.

Tabel 3. Perbedaan prosedur analisis metode AOAC dan Asp

\begin{tabular}{lll}
\hline \multicolumn{1}{c}{ Prosedur Analisis } & \multicolumn{1}{c}{ AOAC } & \multicolumn{1}{c}{ Asp } \\
\hline Hidrolisis protein & Enzim protease, inkubasi 30 menit, & Enzim pepsin, inkubasi 60 menit, \\
& suhu $60^{\circ} \mathrm{C}$ dan $\mathrm{pH} 7,5 \pm 0,1$ & suhu $40^{\circ} \mathrm{C}$ dan pH 1,5 \\
Hidrolisis pati & Enzim amiloglukosidase, inkubasi 30 & Ensim pankreatin, inkubasi 60 \\
& menit, suhu $60^{\circ} \mathrm{C}$ dan $\mathrm{pH} 4,0-4,6$ & menit, suhu $40^{\circ} \mathrm{C}$ dan $\mathrm{pH} 6,8$ \\
Volume Buffer fosfat & $50 \mathrm{ml}$ & $25 \mathrm{ml}$ \\
\hline
\end{tabular}

Berdasarkan penelitian yang membandingkan metode Asp dan AOAC, metode Asp menghasilkan nilai serat pangan total yang lebih tinggi dibandingkan dengan metode AOAC. ${ }^{15}$ Namun metode AOAC ini memiliki akurasi yang lebih tinggi dibandingkan dengan metode Asp. Sehingga metode Asp direkomendasikan sebagai metode yang digunakan untuk analisis serat pangan terutama pada bahan pangan tinggi 
protein. ${ }^{14} \mathrm{Hal}$ ini sejalan dengan penelitian ini yaitu untuk menentukan kadar serat pangan menggunakan metode Asp, karena sebagian besar sampel memiliki kandungan protein yang tinggi.

Pada uji laboratorium, sampel yang digunakan untuk menguji kandungan seratnya berupa makanan yang telah mengalami pengolahan. Berdasarkan penelitian terkait pengaruh perendaman, perebusan dan pemanggang terhadap serat pada kacang-kacangan dan sereal, hasil penelitian menunjukkan sampel yang memiliki kandungan protein tinggi yang diberi perlakuan panas dapat meningkatkan kandungan serat pangan total. Peningkatan serat larut dan tak larut ini dikaitkan dengan adanya produksi dari reaksi maillard. ${ }^{16}$ Adanya kenaikan kadar serat pada makanan yang diamati dalam beberapa penelitian, hal ini biasanya diakibatkan oleh adanya pembentukan kompleks antara polisakarida dan komponen lain dari makanan seperti protein dan senyawa fenolik yang diukur sebagai serat. ${ }^{17}$

Menurut Lintas dan Cappeloni (1988), adanya kehilangan komponen-komponen yang dapat larut dari sayuran seperti gula, protein larut, mineral dan substansi pektat kedalam air perebus akan menurunkan kadar bahan kering, sehingga dapat meningkatkan kadar serat pangan. Demikian pula, adanya kalsium dalam air perebusan memungkinkan terjadinya reaksi dengan substansi pektat yang derajat esterifikasinya rendah membentuk kalsium-pektat yang tidak larut, sehingga akan meningkatkan kandungan serat makanan tidak larut. 18 Selain itu, kenaikan nilai serat pangan tak larut dan serat pangan total akibat proses perebusan mungkin juga disebabkan karena terjadinya reaksi pencoklatan non-enzimatis (antara protein dan gula pereduksi), membentuk polimer yang terhitung sebagai serat pangan. ${ }^{19}$

Selain perlakuan panas dan fermentasi, penyimpanan juga dapat mempengaruhi kandungan serat pada makanan. Selama penyimpanan beberapa sayuran seperti kembang kol, brokoli dan asparagus, dapat mengalami proses pengerasan sehingga dapat meningkatkan kandungan serat serta modifikasi dari komponen serat yang terdiri atas endapan lignin, selulosa, dan hemiselulosa. ${ }^{20}$

Analisis kandungan serat pangan dengan metode nutrisurvey dilakukan dengan memasukkan satu persatu bahan makanan mentah penyusun menu beserta beratnya. Penggunaan bahan makanan mentah dalam analisis nutrisurvey ini tidak memperhitungkan adanya pengolahan makanan, sehingga kadar serat yang dianalisis dengan nutrisurvey lebih rendah nilainya dibandingkan dengan uji laboratorium.

Analisis kandungan serat pangan dengan metode nutrisurvey dilakukan dengan memasukkan satu persatu bahan makanan mentah penyusun menu beserta berat olahannya. Penggunaan bahan makanan mentah dalam analisis nutrisurvey ini tidak memperhitungkan adanya pengolahan makanan, sehingga kadar serat yang dianalisis dengan nutrisurvey lebih rendah nilainya dibandingkan dengan uji laboratorium. Penggunaan bahan makanan mentah pada analisis nutrisurvey disebabkan oleh, tidak semua bahan makanan memiliki bentuk olahannya dalam nutrisurvey. Sementara itu, penggunaan berat bahan makanan olahan dalam nutrisurvey disebabkan, tidak semua bahan makanan memiliki faktor konversi untuk menentukan berat mentah dari bahan masak. Hal ini dapat menjadi salah satu penyebab terjadinya perbedaan hasil serat pada uji nutrisurvey dan enzimatik gravimetri.

Penggunaan database Indonesia (DKBM) dan database negara lain dalam menganalisis kandungan serat pangan pada nutrisurvey, dapat menjadi salah satu faktor adanya perbedaan hasil serat pada nutrisurvey dan enzimatik gravimetri. Hal ini disebabkan karena data yang digunakan memiliki banyak varian dalam pengumpulan 
sampel (seperti varietas, brands, musim, lokasi) serta berbagai faktor yang dapat mempengaruhi kandungan gizi termasuk komposisi tanah/unsur hara dan air, penyimpanan setelah panen, kematangan dan budidaya tanaman. Akibatnya sangat memungkinkan bahwa kandungan gizi dari makanan tertentu akan berbeda dengan nilai yang terdapat dalam DKBM dan database negara lain.

\section{Kesimpulan}

Kesimpulan yang dapat diambil dalam penelitian ini adalah terdapat perbedaan yang signifikan kandungan serat pada menu makanan tradisional khas Indonesia yang dianalisis menggunakan metode nutrisurvey dan uji laboratorium.

\section{Saran} untuk:

Pada penelitian selanjutnya disarankan

1. Penggunaan metode analisis uji laboratorium yang berbeda.

2. Database yang lebih lengkap sehingga memudahkan dalam melakukan input data bahan makanan dalam nutrisurvey.

3. Penambahan sampel makanan pada penelitian selanjutnya

\section{Daftar Pustaka}

1. (WHO) World Health Organization. Obesity and Overweight. (Online). 2015. Diakses $\quad 09 \quad$ April 2015 http://www.who.int/mediacentre/factsheet s/fs311/en/.

2. Gibney MJ et al. Gizi Kesehatan Masyarakat. Jakarta: EGC. 2008. HIm 235.

3. Santoso A. Serat Pangan (Dietary Fiber) dan Manfaatnya Bagi Kesehatan. Magistra. 2011; (75):35-40.

4. Undang-Undang Republik Indonesia Nomor 18 Tahun 2012 Tentang Pangan. Jakarta. 2012. HIm 28-29.
5. Briend A dan Erhadt J. Linear Programming Module of Nutrisurvey. (Online). 2010. Diakses 19 Maret 2015. http/l:www.nutrisurvey.de/lp/lp.htm.

6. Riwidikdo H. Statistik Kesehatan Belajar Mudah Teknik Analisa Data dalam Penelitian Kesehatan. Yogyakarta: Penerbit Mitra Cendekia Press. 2009. HIm 94-98.

7. Tucker LA dan Thomas KS. Increasing Total Fiber Intake Reduces Risk of Weight and Fat Gains in Women. J Nutr Rev. 2009;139:576-581.

8. Muchtadi D. Sayuran sebagai Sumber Serat Pangan untuk Mencegah Timbulnya Penyakit Degeneratif. Ulasan IImiah. Jurnal Teknologi dan Industri Pangan. 2001;12(1):61-71.

9. Student Nutrition Awareness Campaign. Fact of Fiber. University of California. 2005.

10. Leveille GA dan Sauberlich HE. Mechanism of the Cholesterol Depressing Effect of Pectin in the Chilesterol Fed Rat. J Nutr. 1966; 88:209-214.

11. Vasilopoulou $E$ et al. Compatibility of Computed and Chemically Determibed Macronutrients and Energy Content of Traditional Greek Recipes. Journal Of Food Composition and Analysis. 2013; 16:707 - 719.

12. Bedogni $\mathrm{G}$ et al. Comparison of Food Composition Tables and Direct Chemical Analysis for the Assessment of Macronutrient Intake in Military Community. International Journal of Food Science And Nutrition. 1999; 50:73- 79 .

13. Anonim. Association of Anlytical Chemists (AOAC) International. Official Method. 2000; 985.29; 993.19;991.42.

14. Jelita K. Verifikasi Metode Analisis Serat Pangan dengan Metode AOAC dan Asp terhadap Parameter Repeatability, Selektivitas, dan Ruggedness. (Skripsi). Bogor: Institut Pertanian Bogor. 2011. 
15. Aniola J. A Comparison of Two Enzymatic Methods for the Analysis of Dietary Fiber in High-Fiber Preparations. Journal of Nauka Przyroda Technologie. 2007; 1(2):1-6.

16. Azizah $\mathrm{AH}$ dan Zainon $\mathrm{H}$. Effect of Processing on Dietary Fiber Contents of Selected Legumes and Cereals. Mal J Nutr. 1997; 3:131-136.

17. Takeyama E, Yokokawa N, \& Tanimura A. Changes in Polysaccharide Components and Metal Adsorption Ability of Soybean Dietary Fiber on Heating. Journal of The Japanese Society Of Food Science And Technology. 1966; 43:231-237.

18. Lintas $C$ dan Cappeloni M. Content and Composition of Dietary Fiber in Raw and Cooked Vegetables. Hum Nutr Food Sci Nutr. 1988; 42:117-124.

19. Van Soest JP. Use of Detergents in Analysis of Fibrous Feeds: III. Study of Effects of Heating and Drying on Yield of Fiber and Lignin in Forages. The Association of Official Analytical Chemists International. 1965; 48:785790.

20. Rodriguez $\mathrm{R}$ et al. Dietary Fibre from Vegetable Products as Source of Functional Ingredients. Trends in Food Science and Technology. 2006; 17: 3-5. 